\title{
Realization Approach of English Informationization Teaching in Higher Vocational Education
}

\author{
Li Chunyi \\ International Education Department, Hainan College of Economics and Business, Haikou, Hainan, \\ 571100, China
}

Key words: Higher vocational English; Informatization; Teaching

\begin{abstract}
Informationization teaching is a new teaching mode. Closely integrate it with higher vocational English teaching will achieve more diversity in higher vocational English teaching, and improve students' English learning efficiency. At present, higher vocational English informationization teaching is not yet mature, higher vocational English informationization teaching shall be carried out in a steady, timely use, and make it to improve higher vocational English teaching level and quality. This paper explains the realization approach of English informationization teaching in higher vocational education with example analysis.

The 21 st century is an information age, and each domain of the society is closely related to informationization. Education, as a frontier of informationization application, is relying on advanced informationization to promote the reform of education mode. At present, the most domestic higher vocational colleges establish corresponding multimedia classrooms, which is a systematic multimedia teaching technology. But in terms of the openness of informationization teaching model, it appears a certain lag. This paper explains the realization approach of English informationization teaching in higher vocational education with example analysis.
\end{abstract}

\section{THE APPLICATION TREND OF INFORMATION TECHNOLOGY IN HIGHER VOCATIONAL ENGLISH TEACHING}

The Ministry of Education issued Basic Requirements of Higher Vocational English Teaching in October 2000, in which there were principles for higher vocational English teaching like "give priority to practical usage with sufficient degree and solid foundation to cultivate ability", and pay attention to language foundation and the cultivation of language application ability. It is not hard to see that practicability, interactivity and practicality are the three major characteristics of higher vocational college English teaching. With the development of higher vocational education, the traditional teaching mode cannot meet the requirements of the current situation of higher vocational education development [1]. In the development of information technology environment, various applications of information technology are widely used in higher vocational English teaching which can effectively promote the reform of traditional English teaching mode. Micro class refers to a teaching method with videos as the main carrier. The course teachers classify knowledge difficulties and main points and make a few "fragmented" video, using auxiliary teaching resources as implementation not only to help improve the students' interest in learning, but at the same time provide students comprehensive English knowledge.

\section{THE PROS AND CONS OF INFORMATION TECHNOLOGY APPLICATION IN HIGHER VOCATIONAL ENGLISH TEACHING}

Micro class is an important way for the current higher vocational English informatization teaching. This article takes it as an example to discuss the application advantages and disadvantages of higher vocational English informatization teaching to promote the reasonable application of information technology in higher vocational English teaching, and improve the application of information technology effectiveness in higher vocational English teaching [2].

A. Practicability

Informationization teaching has an important practical usage in students' autonomous learning. With the development of network communication and the popularity of microcomputer, autonomous learning has created a kind of inevitable trend. Teachers make the key and difficult problems into informationized teaching course ware, and upload them online to make on-demand learning convenient, which will contribute to the development of classroom teaching. Information-based 
teaching is short, and issues and keys are very bright, which is designed in view of the problems arising from the students' learning so as to conform to the requirements of students' self-study. Students can choose when and where to learn course ware, which provides students with larger independent space. When students have learning desire, self-study can be realized. However, informationization teaching also has some limitations when applied to teaching. When informationization teaching meets relatively complex logic system knowledge, learning effect received is far worse than that of large capacity discipline teaching way.

\section{B. Interactivity}

In higher vocational English traditional teaching mode, single mode is often used, which can't embody English knowledge value effectively, and students' learning interest in English is not high. In addition, higher vocational students' English foundation is relatively weak. There are deficiencies in both learning methods and learning experience, so teachers can apply informationization teaching process to the actual teaching to promote the interaction between teachers and students. Actively carry out English game under the application of informationization, stimulate students interest in learning, and at the same time of finishing the game, implement communication based on task, which may not only help to improve the emotional communication between teachers and students, but also improve students' English learning fun [3]. Teachers through informationization teaching process strengthen students' English learning strategies, like building scene through micro animation and other forms in English writing for students, and guiding the students to from their own imagination in the implementation of English writing. Communicate with students online and promote students' writing key mastery, and dynamically review opinions to make students improve classroom practical writing knowledge transform ability.

Of course, informationization teaching also has some disadvantages. Informationization teaching requires a large amount of information for video and teaching design, and teachers need to use a large amount of time to prepare before class; Informationization teaching is bad for face-to-face communication between teachers and students, and lack of the emotional factors, which is not conducive to harmonious relationship between teachers and students. Specific interactive activities are also inadequate. Informationization teaching only provides students with a learning platform; however, it cannot replace the important role of teacher's teaching.

\section{Practical abilities}

Informationization teaching process can create a good English learning situation for students. Learning English is also the process of language cognition and application, so we must follow the principle of step by step in learning English. Once language knowledge learning is somewhat lax, it is easy to forget, resulting in poor learning effect. In higher vocational English learning, it is mainly as a skill, which also requires students to have a comprehensive understanding of English knowledge, and constantly improves their application ability. The application of informationization can build good English learning situation for students, and let the students fuse into the teaching interaction. Informationization teaching provides conditions for the teaching content of elaborate design, and highlights the teaching focus to improve the quality of classroom teaching.

However, information-based teaching itself has a certain time limit. In order to get good teaching effect, the teaching mission needs to be done within the prescribed period of time [4]. So informationization teaching should combine its own characteristics and the keys for the corresponding teaching content. Teaching practice links of the important contents should be organized to list knowledge more concise, accurate with fully explanation and will not create new problems. It is a fact that informationization teaching video is fragmentation, however, informationization teaching resources should value video integration and systematization, and information-based teaching making is a practice of systematic and solid work.

\section{EXAMPLE ANALYSIS}

Based on our school, this paper selected 4 parallel classes in grade 1 in Administration Department for English informationization teaching reform, and has made significant effect, which is of great significance in speeding up the reform of higher vocational English teaching mode. 


\section{A. Experimental purpose}

With questionnaire, summarize the current situation of English teaching in our school. Select 4 parallel classes in grade 1 in Administration Department according to the survey. The purpose is through contrast test to apply modern informationization in higher vocational English teaching, and to explore the effective method to improve the teaching quality of English information.

\section{B. Design}

Experiment objects are 4 parallel classes in grade 1 in Administration Department, who are randomly divided into experimental class and comparative class. Select two English teachers for experimental class and comparative class teaching by adopting different teaching models. In comparative class, apply traditional English teaching, and in experimental class, apply informationization English teaching. The two classes have the same syllabus, the same textbooks, same teaching progress for contrast effect of English teaching.

1. The main content of information-based teaching mode

Informationization teaching refers to students-centered new teaching method, with use of informationization, such as multimedia, to create different learning environments, such as situation, cooperation, conversation and give full play to students' initiative and enthusiasm [5]. Informationization teaching requires teachers to change their status from knowledge teaching to students learning facilitator, and train students' ability of autonomous learning. After the full study of information-based teaching mode, according to our school's characteristics, cultivate students' comprehensive qualities and comprehensive ability for the teaching target, and put forward six steps teaching method in English teaching. The following six steps are how the teaching method works. Step one: preparation before class. Teachers select teaching video according to the teaching content in advance and let the students watch before class to make the students understand the article scene, and stimulate interest in learning. Step 2: import. After teaching video was over, the teacher ask the students questions. Step 3: division of labor cooperation. Teacher divides the students into learning teams, and let them discuss the proposed problem and summarize. Step 4: classroom demonstration. Let study group elect representatives to speak on the summary view. Step 5: analysis and evaluation. Teacher evaluates each study group's speech, points out the problems and solves them, and decorates in-depth learning requirements. Step 6: expand ability. Teacher takes English content as the center, combines with related social phenomenon, lets the students carry on the independent thinking with the aid of network access to relevant data, and cultivate students' autonomous learning ability.

\section{Improve teachers' comprehensive quality}

Teachers' quality plays a leading role in information-based teaching. Only under the correct guidance of the teacher can students master the correct method of study and improve learning effect. So, to promote informationization teaching in higher vocational English, we must constantly improve the level of teachers' teaching [6]. According to the needs of teaching, our school constructed teachers' teaching skills assessment and evaluation mechanism which is able to timely implement teachers' professional skills assessment and investigation, and balance the skill levels of teachers with the new teaching mode.

3. Do good teaching resources development job

Classroom teaching video clips are the core of information-based teaching, and teaching design, material course ware, teaching reflection and practice test are integral parts of informationization teaching. It is simple to make one section of information teaching course, but how to make a system of the informationization teaching course is of certain difficulty. As a result, we must attach importance to informationization teaching resources development, which requires the teachers do by heart, and constantly develop informationization teaching resources. In the development of informationization curriculum resources, the teachers should connect each link organically, and realize the application value of informationization teaching. First, make sure the teaching aim and teaching content of informationization, make the detailed division of the knowledge taught, and design information courses and course ware based on the characteristics of students' learning lesson plans. Secondly, design students' interested teaching videos, and according to students' feedback 
information in time optimize them. Finally, information course knowledge system should have integrity, and train students' autonomous learning ability [7]. In the development of informatization in our English teaching resources, adhere to the above principles, at the same time, attach importance to English learning network platform construction, share a lot of good resources for students to learn English through the network platform, and establish teacher E-mail system, on-line question-answering system, online homework evaluation system and English discussion BBS, which will greatly improve the students' English learning efficiency.

\section{Result analysis}

After a semester of experiment teaching and comparison, experimental class students' English learning motivation is higher than many other classes. Through statistical analysis of students' English final exam results, it is found that experimental class student's English achievement is significantly higher than that in comparative class, and experimental class students' integrated English level has been greatly ascended.

\section{CONCLUSION}

To sum up, informationization teaching is a new type of teaching mode which receives modern teaching idea, and is based on informationization support. Currently, the method of teaching English is becoming more and more diversified. How to effectively combine English teaching with modern informationization is an important issue in higher vocational English teaching reform. This paper explores the advantage of higher vocational English informatization teaching mode by comparing information-based teaching mode and the traditional teaching mode, and puts forward concrete suggestions on how to push forward informationalization teaching in higher vocational English.

\section{REFERENCES}

[1] Jiang Youjun. Higher vocational English autonomous design learning in information-based teaching environment [J]. Journal of Science and Technology Information, 2012, 4:76-77.

[2] Li Yalin. Higher vocational English teachers informatization teaching team construction path analysis [J]. Journal of Xiangyang Vocational and Technical College, 2014,01:83-86.

[3] Liu Ruina. Higher vocational English teachers' informationization teaching ability exploration [J]. Journal of Human Resource Development, 2014, 20:180-181.

[4] Zhang liang. higher vocational English informatization teaching design exploration based on project teaching $[\mathrm{J}]$. Science Tribune (ten-day), 2014, 11:150 + 177 .

[5] Wu Binyu. MOOC exploration and application in higher vocational English informatization teaching [J]. Journal of Nanning Vocational and Technical College, 2015 01:60-62.

[6] Zhou Yongxiang. The application of micro in higher vocational English informatization teaching [J]. Journal of Chongqing Electronic Engineering Vocational College, 2015, 119:119-121.

[7] Miao Kun. E era higher vocational English network informationization teaching strategy exploration [J]. Journal of Nanchang Institute of Education, 2013, 11:99-100. 